\title{
Research on land consolidation mode of whole village in Yunnan Province
}

\author{
Zheng Honggang ${ }^{1,2, a}$, Yu Jianxin ${ }^{1,2}$, Li Yanqiong ${ }^{3}$, Liao Lijun ${ }^{1,2}$, Zhang \\ Jiansheng ${ }^{1,2}$ \\ ${ }^{1}$ college of Water Resources and hydraulic engineering, Yunnan Agricultural University, \\ Kunming ,China; \\ ${ }^{2}$ Engineering Research Center of Science and Technology of Land and Resources, Yunnan \\ Agricultural University, Kunming,China; \\ ${ }^{3}$ Yunnan Agricultural University Library, Kunming ,China \\ ânhg61@126.com
}

\begin{abstract}
Keywords: The whole village construction, land consolidation Mode,Fragmented, Middle and low yield fields, Quality of arable land

Abstract: In order to make clear the priority of land consolidation, improve the use efficiency of land consolidation funds, and promote the better land consolidation work. Based on the investigation and summary of the current problems in land consolidation, according to the characteristics of land use in Yunnan Province, the factors such as renovating objects, construction conditions, construction contents, investment standards and construction methods are analyzed and discussed. 7 kinds of land consolidation models suitable for the whole village in Yunnan province were put forward. After the whole village is promoting the land consolidation, the quality of the cultivated land with poor quality has been improved greatly. The whole village land consolidation mode has important significance to improve the quality of low yield farmland, low yield fields should be used as the preferred land remediation remediation object, the whole village land consolidation mode can solve the scattered low yield farmland remediation problems, can save $20 \%-35 \%$ funds, is an effective way to improve the efficiency of the use of land remediation funds.
\end{abstract}

\section{Introduction}

The issue of "arable land, population and food" has always been a major issue facing the development of our country. In response to the severe situation of arable land in our country and in order to ensure the sustainable development of our society and economy, the issue of using cultivated land, increasing the quality of cultivated land and increasing effective cultivated land Land consolidation, the main purpose of improving agricultural production conditions and ecological environment, came into being in the late 1990s. Although land consolidation started relatively late in our country, its work has been carried out more rapidly, a great deal of land has been developed and arranged, an effective cultivated land has been newly added, and a positive contribution has been made to ensuring the dynamic balance of total cultivated land and the macroeconomic strategy of food security. Statistics show that according to relevant statistics, as of now, the funds invested in land remediation throughout the country have reached over 1 trillion yuan in total.

However, part of the project investment and construction did not achieve the desired effect, in order to effectively make comprehensive land consolidation work, in-depth analysis of the problems existing in the land remediation project, put forward the entire village to promote land remediation mode, providing another idea of land remediation, To avoid duplication of construction projects and waste of funds for the management of land remediation project decision-making to provide a reference.

As a result, there are many reasons for the inefficient investment in some projects. There are many reasons for the waste of funds: there are problems that the project management is not in place, 
the problems that the planning and design are not practical, the problems with the right adjustment, the problems that the supervision is ineffective, and the project completion Acceptance is not strictly the problem. In addition to the above reasons, the fixed project construction mode and construction content are also one of the major causes of the waste of funds.

The current project site selection generally requires centralized contiguous pursuit of one-sided concession, resulting in duplication of investment and waste of funds in contiguous cultivated land. However, scattered middle and low-yield fields that need to be rehabilitated can not be improved $[1-4]$.

In addition, part of the planning and design of the project is not practical and poorly targeted. Many unnecessary contents are built. The standard of investment per unit area is the same, resulting in waste of funds.

\section{The significance of promoting the construction of land consolidation project in the whole village}

\section{Land consolidation in the whole village can make scattered and fragmented cultivated land reformed and upgraded}

The geological structure of Yunnan is complex, the terrain is broken and the types of geomorphology are varied. In the area of high mountains and steep slopes, mountainous and hilly area of the total $94 \%$, accounting for only $6 \%$ of the plain. The characteristics of Yunnan's topography and geomorphology determine the characteristics of cultivated land distribution: the land area is wide, but the mountainous area is many, the plain is few, and the cultivated land is scarce. Most of the cultivated land is scattered in the hilly area, which is inlaid with the woodland, and the concentration is poor. The quality of cultivated land is poor, and the middle and low yield fields are the main.

Medium and low-yield fields are those with poor environmental conditions. Comprehensive agricultural techniques (including farmland water conservancy design, crop layout, tillage system, fertilization measures, etc.) are not high and crop environmental factors (including light, temperature, precipitation, topography, soil properties, etc. ) With uncoordinated, low-yielding arable land ${ }^{[5]}$. Taking Yunnan Province as an example, the result of agricultural land grading shows that the province has a total of 6.1196 million $\mathrm{hm} 2$ of cultivated land and 4.584 million $\mathrm{hm} 2$ of middle and low-yield land, accounting for $74.91 \%$ of the cultivated land ${ }^{[6]}$.

The infrastructure of middle-high yielding fields is generally relatively complete, and the quality of arable land is good. There is limited space for improving cultivated land quality through land remediation. Due to soil and water constraints, the quality of arable land in low and middle-yielding fields is generally poor. After land reclamation, after solving the factors that restrict the quality of arable land, the quality of middle and low-yield land is greatly improved. Therefore, the middle and low yield land is the main target of land remediation.

Whole village land remediation refers to the village as a unit, all the farmland within the village for a one-time remediation. Taking the whole village to promote the way of land remediation, can make all the cultivated land within the entire village governed, for the fragmented low-middle-class cultivated land provided improvement opportunities.

The construction of the project is more in line with the actual needs, and the use of funds is more reasonable.

The construction of land remediation projects generally include land leveling works, irrigation and drainage works, field road works and soil and water conservation and farmland protection works.

Reasonably determine the construction content is the premise of the rational use of funds. The content of construction should be determined according to the land use restriction factors in the project area, and the irrigation areas are mainly constructed in arid areas. Waterlogging, drainage is not smooth areas focusing on the construction of drainage facilities. The southern rainfall rich hilly 
mountains, natural rainfall can basically meet the irrigation requirements, focusing on the implementation of land leveling project and field road engineering.

According to the restriction factors of land use in the project area, the content of construction can be determined according to local conditions, which can avoid the one-sided pursuit of high standards of engineering facilities, make the use of funds more reasonable and avoid unnecessary waste of funds.

\section{The entire village to promote land remediation can promote rural settlement and new rural} construction

The rapid development of urbanization leads to the existence of a large number of hollow villages, idle houses and low land use rate in rural land use.

The rural settlement is one of the effective ways to improve the efficiency of land use, improve the living conditions of the residents, increase the number of cultivated land and ensure the security of grain ${ }^{[7-11]}$.

According to the spirit of the state, the overall requirements of urban and rural development and new rural construction should be coordinated. On the basis of full respect for farmers' wishes, we should actively and steadily promote village arrangement and promote the development of agricultural production to scale management. Promoting land consolidation in the whole village can be combined with the requirements of the new rural construction, supporting the implementation of the village infrastructure construction, which is conducive to the rational layout, and once planning is in place, reducing duplication of waste. Whether land ownership adjustment is in place is one of the key factors for land consolidation projects to be implemented according to plan. Promoting land consolidation in the whole village is conducive to the development of land ownership adjustment.

\section{Whole village to promote land remediation project construction mode}

The whole village promotion plan of land consolidation is to bring all the cultivated land in the 1 2 village committees into one project and put forward 7 kinds of land consolidation Mode. The construction standards, construction conditions, investment standards and construction methods have been put forward in each land consolidation Mode. The specific contents and control indicators of land consolidation Mode are detailed in Table 1.

The core of land consolidation project is land leveling engineering. Through land leveling, the evenness of field surface is improved, and the soil texture is more homogeneous. After 3 5 years, the fertility of soil will gradually recover, and the quality of cultivated land will be improved significantly. Besides, land leveling can also increase the area of effective cultivated land, increase surface runoff and infiltration, increase soil water content, reduce soil erosion, improve agricultural production conditions and ecological landscape effects. Therefore, in the 7 modes of land consolidation project construction proposed by the whole village, each mode includes land leveling engineering, and field roads, irrigation and drainage works can be determined according to specific circumstances and actual needs.

\section{The object and target of land consolidation}

In the 7 regulation modes of land consolidation in the whole village, the object of $1 \sim 5$ mode is low yield field, and the target of construction is low yield field transformation. The quality of cultivated land after rectification is improved obviously. The target of the sixth models is the middle yield field, the construction target is the middle yield field transformation, the construction standard is high, the quality of cultivated land after the consolidation is improved. The seventh mode of regulation can be low yield fields and middle fields. The target is high standard basic farmland construction, and the construction standard is high. After rectification, the quality of cultivated land should meet the requirement of high standard basic farmland.

\section{Construction conditions and construction content}

In the 7 regulation modes of land consolidation in the whole village, 1 or 2 modes of renovation are very fragmented, with only a small block area, so they do not have the conditions to build field 
roads and system supporting facilities. Mode 1 is suitable for humid areas, rainfall basically meet the irrigation needs, not need the construction of water conservancy facilities; mode 2 is suitable for arid area, built cellar, pools of rainwater for irrigation.

The control objects of the third, fourth models are scattered, and the area of the single block is small, and the conditions for building a certain number of field roads are provided. On the basis of the 1 and 2 models, a small amount of field roads are added to meet the needs of the transportation of agricultural products.

The fifth modes of land consolidation are relatively concentrated. The area of a single block has a certain scale. It has the conditions of building certain field roads and water conservancy facilities, and builds field road projects and irrigation works according to the lower construction standards.

The sixth modes of land consolidation are concentrated, with large single block area, with the conditions of building field roads and water conservancy facilities, and supporting the construction of field road projects and farmland water conservancy projects according to higher engineering construction standards.

The seventh modes of land consolidation object concentrated, single block area, with the construction of water conservancy facilities and road conditions, the implementation of land consolidation project, field road engineering and water conservancy projects by supporting the highest standard of engineering construction, after the completion of the project to achieve high standards of basic farmland.

\section{Investment standards and construction methods}

The investment standard is determined according to the specific construction content, and investment per hectare is 6,000-60000 yuan. On the mode of construction, the construction of a small area and a low investment standard may be constructed by farmers themselves or by the villagers 'committees themselves Construction , by the Management department acceptance. For the plot of cultivated land contiguous with high investment standards, according to the national construction project management procedures.

\begin{tabular}{|c|c|c|c|c|c|}
\hline mode & $\begin{array}{c}\text { construction } \\
\text { orientation }\end{array}$ & Construction Content & Construction conditions & $\begin{array}{c}\text { Investment } \\
\text { Standard }\end{array}$ & Construction methods \\
\hline 1 & $\begin{array}{l}\text { upgrading low and } \\
\text { medium yield } \\
\text { farmland }\end{array}$ & Land leveling & $\begin{array}{c}\text { The cultivated landis } \\
\text { scattered, with a single area of } \\
\text { less than } 3.33 \text { hectares } \\
\text { Humid area }\end{array}$ & $\begin{array}{c}6000-9000 \text { yuan } \\
/ \text { hectare }\end{array}$ & $\begin{array}{l}\text { Farmers self-built, the } \\
\text { project investor acceptance }\end{array}$ \\
\hline 2 & $\begin{array}{l}\text { upgrading low and } \\
\text { medium yield } \\
\text { farmland }\end{array}$ & $\begin{array}{l}\text { Land leveling } \\
\text { The construction of } \\
\text { water cellar }\end{array}$ & $\begin{array}{c}\text { The cultivated land is } \\
\text { scattered, with a single area of } \\
\text { less than } 3.33 \text { hectares } \\
\text { dry area }\end{array}$ & $\begin{array}{c}7500-13500 \\
\text { yuan / hectare }\end{array}$ & $\begin{array}{l}\text { Farmers self-built, the } \\
\text { project investor acceptance }\end{array}$ \\
\hline 3 & $\begin{array}{l}\text { upgrading low and } \\
\text { medium yield } \\
\text { farmland }\end{array}$ & $\begin{array}{l}\text { Land leveling } \\
\text { Build field road }\end{array}$ & $\begin{array}{c}\text { The cultivated land is } \\
\text { scattered, with a single area of } \\
3.33-13.33 \text { hectare } \\
\text { Humid are }\end{array}$ & $\begin{array}{c}9000-13500 \\
\text { yuan / hectare }\end{array}$ & $\begin{array}{l}\text { Village committee } \\
\text { self-built, the project } \\
\text { investor acceptance }\end{array}$ \\
\hline 4 & $\begin{array}{l}\text { upgrading low and } \\
\text { medium yield } \\
\text { farmland }\end{array}$ & $\begin{array}{l}\text { Land leveling } \\
\text { Build field road } \\
\text { The construction of } \\
\text { water cellar } \\
\text { Land leveling }\end{array}$ & $\begin{array}{l}\text { The cultivated landis } \\
\text { scattered, with a single area of } \\
3.33-13.33 \text { hectare } \\
\text { dry area }\end{array}$ & $\begin{array}{l}12000-18000 \\
\text { yuan / hectare }\end{array}$ & $\begin{array}{l}\text { Village committee } \\
\text { self-built, the project } \\
\text { investor acceptance. }\end{array}$ \\
\hline 5 & $\begin{array}{l}\text { upgrading low and } \\
\text { medium yield } \\
\text { farmland }\end{array}$ & $\begin{array}{l}\text { Build field road } \\
\text { Build a small amount of } \\
\text { water conservancy } \\
\text { facilities }\end{array}$ & $\begin{array}{l}\text { The cultivated land is } \\
\text { f relatively concentrated, with an } \\
\text { area of } 13.33-33.33 \text { hectares }\end{array}$ & $\begin{array}{l}15000-22500 \\
\text { yuan / hectare }\end{array}$ & $\begin{array}{l}\text { According to the national } \\
\text { construction project } \\
\text { management procedures }\end{array}$ \\
\hline 6 & $\begin{array}{l}\text { upgrading medium } \\
\text { yield farmland }\end{array}$ & $\begin{array}{c}\text { Land leveling } \\
\text { Build field road } \\
\text { Construction of basic } \\
\text { water conservancy } \\
\text { facilities }\end{array}$ & $\begin{array}{l}\text { The cultivated land is } \\
\text { concentrated, with an area of } \\
33.33-66.67 \text { hectares }\end{array}$ & $\begin{array}{l}22500-30000 \\
\text { yuan / hectare }\end{array}$ & $\begin{array}{l}\text { According to the national } \\
\text { construction project } \\
\text { management procedures }\end{array}$ \\
\hline 7 & $\begin{array}{l}\text { High standard basic } \\
\text { farmland } \\
\text { construction }\end{array}$ & $\begin{array}{c}\text { Land leveling } \\
\text { Building a high } \\
\text { standard field road } \\
\text { Construction of high } \\
\text { standard water } \\
\text { conservancy facilities }\end{array}$ & $\begin{array}{l}\text { The cultivated land was } \\
\text { concentrated, with a single area } \\
\text { of more than } 66.67 \text { hectares }\end{array}$ & $\begin{array}{l}30000-60000 \\
\text { yuan } / \text { hectare }\end{array}$ & $\begin{array}{l}\text { According to the national } \\
\text { construction project } \\
\text { management procedures }\end{array}$ \\
\hline
\end{tabular}




\section{case analysis}

Yunnan Province, a village belonging to the mountain area, land area of 34.90 square kilometers, with an altitude of 1850 to 2536 meters, the annual average temperature of 13 degrees, annual rainfall of $850 \mathrm{~mm}$, suitable for planting crops of tobacco, corn, rice, barley and wheat, farmers' income mainly dominated by farming. There are 13 villager groups in the village, including 898 farmers, 3158 agricultural population, 289.12 hectares of cultivated land, 84.35 hectares of paddy fields, $29.17 \%$, and 204.77 hectares of dry land, accounting for $70.83 \%$. The cultivated land is fragmentary, and the whole village is divided into 61 plots. The quality of the current cultivated land is as follows: the physical quality grade is 10.23 , the utilization quality grade is 9.69 , the economic quality composite grade is 8.98 , etc. Among them, the physical quality grade value of paddy field is 9.16 , and utilization quality grade is 8.41 . The economic quality composite grade is 7.85. The the physical quality grade of dry land is 10.67 , The utilization quality grade is 10.22 , and the economic quality composite grade is 9.45 .

To promote land consolidation through the whole village, the construction of irrigation and drainage, field traffic and other facilities, The quality of the cultivated land is greatly improved, the physical quality grade increase of 0.85 , with the utilization quality grade increase of 1.17 , the economic quality composite grade increase of 1.23 . After dry land into irrigated land, the quality is very large increase, the physical quality grade increase of 1.31 , with the utilization quality grade increase of 1.90, the economic quality composite grade increase of 1.82 . paddy field before and after regulation of quality of the cultivated land changed little, the physical quality grade increase of 0.04 , the utilization quality grade increase of 0.14 , the economic quality composite grade increase of 0.20 .

The change of the quality of cultivated land before and after the land consolidation is detailed in table 2- 4 .

Table 2 Statistical table of changes of arable land physical quality grade before and after land consolidation $\left(\mathrm{hm}^{2}\right)$

\begin{tabular}{ccccccccccc}
\hline physical & \multicolumn{4}{c}{ consolidation before } & \multicolumn{4}{c}{ consolidation after } \\
\cline { 2 - 9 } $\begin{array}{c}\text { quality } \\
\text { grade }\end{array}$ & 9 & 10 & 11 & $\begin{array}{c}\text { Number weighted } \\
\text { of plots }\end{array}$ & mean & 9 & 10 & $\begin{array}{c}\text { Number } \\
\text { of plots }\end{array}$ & $\begin{array}{c}\text { weighte } \\
\text { d mean }\end{array}$ \\
\hline dry land & 0.00 & 47.57157 .20 & 60 & 10.67 & 0.00 & 35.63 & 34 & 10.13 \\
$\begin{array}{c}\text { Irrigated } \\
\text { land }\end{array}$ & 0.00 & 0.00 & 0.00 & 0 & 0.00 & 169.14 & 0.00 & 26 & 9.36 \\
$\begin{array}{c}\text { Paddy } \\
\text { field }\end{array}$ & 84.35 & 0.00 & 0.00 & 1 & 9.16 & 84.35 & 0.00 & 1 & 9.12 \\
total & 84.35 & 47.57157 .20 & 61 & 10.23 & 253.49 & 35.63 & 61 & 9.38 \\
\hline
\end{tabular}

Table 3 Statistical table of changes of arable land utilization quality grade before and after land consolidation ( $\mathrm{hm}^{2}$ )

\begin{tabular}{ccccccccccccc}
\hline $\begin{array}{c}\text { utilization } \\
\text { quality } \\
\text { grade }\end{array}$ & 8 & 9 & 10 & \multicolumn{4}{c}{$\begin{array}{c}\text { Numberweighted } \\
\text { of plots }\end{array}$} & mean & 8 & 9 & $10 \begin{array}{c}\text { Number } \\
\text { of plots }\end{array}$ & $\begin{array}{c}\text { ceighted } \\
\text { mean }\end{array}$ \\
\hline dry land & 0.00 & 47.57157 .20 & 60 & 10.22 & 0.00 & 0.0035 .63 & 34 & 10.07 \\
$\begin{array}{c}\text { Irrigated } \\
\quad \text { land }\end{array}$ & 0.00 & 0.00 & 0.00 & 0 & 0.00 & 169.140 .00 & 0.00 & 26 & 8.32 \\
$\begin{array}{c}\text { Paddy } \\
\text { field }\end{array}$ & 84.35 & 0.00 & 0.00 & 1 & 8.41 & 84.35 & 0.00 & 0.00 & 1 & 8.27 \\
total & 84.3547 .57157 .20 & 61 & 9.69 & 253.490 .0035 .63 & 61 & 8.52 \\
\hline
\end{tabular}

Table 4 Statistical table of changes of arable land economic quality composite grade before and after land consolidation (hm ${ }^{2}$ )

\begin{tabular}{|c|c|c|c|c|c|c|c|c|c|}
\hline \multirow{2}{*}{$\begin{array}{c}\text { economic } \\
\text { quality } \\
\text { composite } \\
\text { grade }\end{array}$} & \multicolumn{5}{|c|}{ consolidation before } & \multicolumn{4}{|c|}{ consolidation after } \\
\hline & 7 & 8 & 9 & $\begin{array}{l}\text { Number } \\
\text { of plots }\end{array}$ & $\begin{array}{c}\text { weighted } \\
\text { mean }\end{array}$ & 7 & 8 & $\begin{array}{c}\text { Number } \\
\text { of plots }\end{array}$ & $\begin{array}{c}\text { weighted } \\
\text { mean }\end{array}$ \\
\hline dry land & 0.00 & 0.00 & 204.77 & 60 & 9.45 & 0.00 & 35.63 & 34 & 9.42 \\
\hline $\begin{array}{c}\text { Irrigated } \\
\text { land }\end{array}$ & 0.00 & 0.00 & 0.00 & 0 & 0.00 & 169.14 & 40.00 & 26 & 7.63 \\
\hline $\begin{array}{c}\text { Paddy } \\
\text { field }\end{array}$ & 84.35 & 0.00 & 0.00 & 1 & 7.85 & 84.35 & 0.00 & 1 & 7.65 \\
\hline total & 84.35 & 0.00 & 204.77 & 61 & 8.98 & 253.49 & 935.63 & 61 & 8.86 \\
\hline
\end{tabular}


In terms of project investment, compared with the conventional land consolidation project investment of 30000-35000 yuan per hectare, the whole village's land consolidation can save $20 \%-35 \%$ funds and investment efficiency is higher. The investment situation is detailed in Table 5.

\begin{tabular}{ccccr}
\multicolumn{4}{l}{ Table 5 the whole village land consolidation and Investment situation } \\
\hline Mode & $\begin{array}{c}\text { Number of } \\
\text { plots }\end{array}$ & Area/ $\mathrm{hm}^{2}$ & $\begin{array}{c}\text { Investment } \\
\text { per hectare / yuan }\end{array}$ & $\begin{array}{c}\text { Investment } \\
\text { / million yuan }\end{array}$ \\
\hline $\begin{array}{c}\text { Less than 3.33 } \\
\text { hectares }\end{array}$ & 48 & 39.55 & 12000 & 47.46 \\
3.33-13.33 hectares & 8 & 52.38 & 15000 & 78.58 \\
$\begin{array}{c}\text { 13.33-33.33 hectares } \\
\text { 33.33-66.67 hectares }\end{array}$ & 3 & 65.27 & 22500 & 146.87 \\
$\begin{array}{c}\text { 66.67 hectares or } \\
\text { more }\end{array}$ & 1 & 47.57 & 30000 & 142.70 \\
total & 61 & 289.12 & 24870 & 303.65 \\
\hline
\end{tabular}

\section{Conclusion}

land consolidation has a significant increase in the quality of the low grade cultivated land (dry land). The middle and low yield fields should be the priority objects for land consolidation. The whole village's land consolidation mode has a significant effect on improving the overall quality of the middle and low yield fields.

for land with complex topography and fragmented areas, a combination of one or several modes in the seven modes of whole village promoting land remediation can save $20 \%-35 \%$ funds, which is an effective way to improve the efficiency of land remediation funds.

\section{Acknowledgements}

This work was financially supported by Research subject of state science and technology support program (2015BAD06B04).

\section{References}

[1] J. WANG, L. N. ZHONG. Literature Analysis on Land Consolidation Research in China. China Land Sciences, Vol. 30 (2016), No4, p.88-96.

[2] Z. J. FENG, Y. D. ZHENG, Discussion on the land unknitting problem in land consolidation and consolidation project. Resources \& Industries, Vol. 7(2005), No2 , p.80-82.

[3] X. R. ZHANG, T. W. WANG, W. GUO et al. The Basic Features, Existing Problems and Suggestions of Chinese land Develop and Arrangement. Science Technology and Industry, Vol. 10(2010), No8, p.54-61.

[4] J. M. YAN, F. Z. XIA, M. MA. Strategy Orientations of Transformation Development: Land Consolidation in the New Period of China. China Land Sciences, Vol. 30(2016), No2, p.3-10.

[5] Q. H. Shi, H. Wang, F. Chen et al. The Spatial-Temporal Distribution Characteristics and Yield Potential of Medium-low Yielded Farmland in China. Chinese Agricultural Science Bulletin, Vol. 26(2010), No19, p.369-373.

[6] J. S. ZHANG, S. WANG, C. ZHANG et al. Study on the Division of Medium-low-yield Field Basedon Agricultural Land Classification. Journal of Yunnan Agricultural University, Vol. 25(2010), No4, p.556-561.

[7] W. J. Yun, Z. R. Yu. Ecological landscaping strategy of rural land consolidation in China. Transactions of the Chinese Society of Agricultural Engineering, Vol. 27(2011), No4, p. 1-6. 
[8] B. J. Yang, W. J. Yun, S. X. Liu et al. Investigation on the Farm land Consolidation Projectfor Development of Border Area. China Development, (2010), No2, p.4-8.

[9] Y. B. Feng, Q. Y. Yang. Key research fields and basic directions of Chinese rural-land comprehensive consolidation in transitional period. Transactions of the Chinese Society of Agricultural Engineering, Vol. 30(2014), No1, p.175-182.

[10] L. H. Kuang, Y. C. Ye, X. M. Zhao et al. Evaluation on influence of land consolidation project on cultivated land quality based on agricultural land classification correction method Transactions of the Chinese Society of Agricultural Engineering, Vol. 32(2016), No9, p.198-205.

[11] X. R. SUN, X. W. ZHOU, Z. Q. WANG et al. Research on the Correlation of Rural Land Consolidation and Ecological Civilization Construction. Research of Soil and Water Conservation, Vol. 24(2017), No2, p.268-271. 